\title{
Influence of Dietary Natural Veterinary Medicine (Minyak Rajas) on Growth Performance and Blood Profile of Growing Roosters
}

\author{
I Wayan Sudira ${ }^{*}$, Anak Agung Gde Arjana ${ }^{1}$, I Wayan Nico Fajar Gunawan², Luh Made \\ Sudimartini ${ }^{2}$, I Made Merdana ${ }^{1,2}$
}

${ }^{1}$ Physiology, Pharmacology, and Veterinary Pharmacy Laboratory, Departement of Veterinary Basic Science, Faculty of Veterinary Medicine, Udayana University, Denpasar, Bali-80234; ${ }^{2}$ Department of Veterinary Clinic, Faculty of Veterinary Medicine, Udayana University, Denpasar, Bali-80234, Indonesia.

\begin{abstract}
The use of natural medicines to improve the performance of chickens is increasingly in demand by poultry producers as well as consumers because of their safety. This study aims to determine the impact of supplementation of natural veterinary medicine (viz., Minyak Rajas (MR)) through feed on the performance and blood profile of grower phase fighting roosters. Sixty (60) fighting roosters were raised in individual cages and randomly divided into four groups. The MR was administrated through feed with respective doses of $0,0.1,0.2$, and $0.4 \mathrm{ml} / \mathrm{kg} / \mathrm{day}$ for seven weeks. The results showed a significant $(\mathrm{p}<0.05)$ increase in the cumulative voluntary feed intake, the cumulative body weight, the average daily weight gain, and the feed conversion efficiency in MR administered groups as compared to the control group. The best performance was exhibited $(\mathrm{p}<0.05)$ by the $0.2 \mathrm{ml} / \mathrm{kg} /$ day treatment group as compared to the control and other treatment groups. Total erythrocyte count and mean corpuscular haemoglobin concentration (MCHC) were also found higher $(\mathrm{p}<0.05)$ in the $0.2 \mathrm{ml} / \mathrm{kg} /$ day MR treatment group when compared with the control group. However, other haematological and biochemical indicators remained unaffected by the dietary treatments and their values were in the normal range. In conclusion, the supplementation of natural animal medicine MR have a beneficial effect on the health and performance of the grower phase fighting roosters.
\end{abstract}

Keywords | Fighting rooster, Natural veterinary medicine, Minyak Rajas, Growth performance, Blood profile.

Received | December 29, 2020; Accepted | January 19, 2021; Published | February 20, 2021

*Correspondence | I Wayan Sudira. Physiology, Pharmacology, and Veterinary Pharmacy Laboratory, Departement of Veterinary Basic Science, Faculty of Veterinary Medicine, Udayana University, Denpasar, Bali-80234, Indonesia; Email: wayan.sudira@unud.ac.id

Citation | Sudira IW, Arjana AAG, Gunawan IWNF, Sudimartini LM, Merdana IM (2021). Influence of dietary natural veterinary medicine (minyak rajas) on growth performance and blood profile of growing roosters. J. Anim. Health Prod. 9(2): 140-147.

DOI | http://dx.doi.org/10.17582/journal.jahp/2021/9.2.140.147

ISSN | 2308-2801

Copyright (c) 2021 Sudira et al. This is an open access article distributed under the Creative Commons Attribution License, which permits unrestricted use, distribution, and reproduction in any medium, provided the original work is properly cited.

\section{INTRODUCTION}

$\mathrm{I}$ ndonesia has at least 32 local chicken types as genetic resources; one is Balinese chickens. Local chickens reared for two purposes, namely meat and egg production, while a third category is fighting roosters, which is a comparatively high-cost chicken (Nataamijaya, 2010). Stages of raising native chickens are divided into the starter phase ( $0-8$ weeks), grower phase (9-15 weeks), and then developer-finisher phase ( $>15$ weeks age) (Vasinopas and Meckvichai, 2015). To increase the performance of local chickens, breeders had crossbred local chickens with good exotic chicken strains. Some of the imported fighting roosters used were Lancy, Clarret, Sweater, Gold whithe, and Peruvian roosters. Cross-breeding of these non-native chickens with Balinese chickens produced fighting roosters with good performance. To get the good quality cross-breed fighting roosters, breeders follow a strict selection process starting from the starter phase (Hidayat and Asmarasari, 2015; Ulfah et al., 2015). Chickens that do not pass the selection procedure removed to consumption stock. The success of animal husbandry requires genetic resources, nutrition, good management, strict prophylytic medication, and biosecurity plans (Ardana, 2011). The 
use of natural growth promoters is increasing due to safety reasons. One of the herbal products that are widely used by breeders is Minyak Rajas (MR) which is a commercial product produced by PT. Songgolangit Persada, Indonesia. Minyak Rajas is a natural veterinary medicine formulated from various herbs based on EM (effective microorganism) technology. The active ingredients of this product includes, coconut oil, Zingiberis rbizoma, Languatis rbizoma, Curcuma rhizomes, Imperatae rbizoma, betel leaf (Piper betle L.), and Zingiber purpureum rhizomes. Coconut oil contains various energy-rich substances like triglycerides, lauric acid, stearic acid, and linoleic acid (Intahphuak et al., 2010); Zingiberis rbizoma contains several antioxidants like zingiberene, zingiberol, cineole, and quercetin (Mao et al., 2019). Languatis rbizoma possess eugenol, sesquiterpenes, methyl cinnamic, and kaempferia (Kaliyadasa and Samarasinghe, 2019). The rhizomes of curcuma sp. have several antioxidant, anti-inflammatory and antimicrobial compounds viz., curcuminoid compounds, flavonoids, and triterpenoids (Rohaimi et al., 2012; Simoh and Zainal, 2015). The Imperatae rbizoma contains alkaloids, flavonoids, steroids, triterpenoids, tannins, and phenolics (Liu et al., 2010). Betel leaf (Piper betle L.) contains saponins, flavonoids, and polyphenols in both plant parts and its' essential oil (Syahidah et al., 2017). Zingiber purpureum rhizome contains flavonoids, saponins, tannins, triterpenoids, cineole, and essential oils (Astarina et al., 2013). These active compounds are reported to have pharmacological effects such as antioxidants, antimicrobials, anti-inflammatory, analgesic, antipyretic, cholesterol-lowering, hepatostimulant, immunostimulant, anticancer, and anti-helminthic (Maneewan et al., 2011; Spriridonov, 2012; Labban, 2014; Omonijo et al. al, 2018; Merdana et al., 2019; Ahlina et al., 2020; Ahmad et al., 2020). MR has a slightly thick oily texture, yellowish-brown color, and has a distinctive aroma with a $\mathrm{pH}$ about 5-6.

It is well established that drugs that can maintain the health of the digestive tract of animals have a boosting impact on nutrient absorption, growth, and feed digestion efficiency (Mustchler, 2001; Katzung, 2004). MR is known to have ameliorative effects against various diseases of the digestive system of animals and worm infestation. Chicken breeders also believed that it can significantly increase muscle growth in fighting roosters probably due to improvement in nutrient absorption. The supplemental dosage of MR for ruminants is $0.02-0.04 \mathrm{ml} / \mathrm{kg}$, while for avian is $0.1-$ $0.4 \mathrm{ml} / \mathrm{kg}$ body weight.

Unfortunately, there is no published literature is available on the supplemental effect of MR in fighting roosters. Therefore, current study was carried out to investigate the effects of dietary supplementation of MR on performance, haematological indices and blood biochemical profiles of fighting roosters.

\section{MATERIALS AND METHODS}

\section{ETHICAL CLEARANCE}

The procedure for using experimental animals were approved by the Veterinary Ethics Committee of the Faculty of Veterinary Medicine, Udayana University (Approval letter number: 15 / UN14.2.9 / PT.01.04 / 2020). The research location was the Centre of Fighting Chicken Farming located in Madenan Village, Buleleng Regency, Bali Province, Indonesia. Blood tests were carried out at the Laboratory of Veterinary Physiology, Pharmacology, and Pharmacy, Faculty of Veterinary Medicine, Udayana University.

\section{Animals and Management}

Eight weeks old, healthy cross-breed fighting roosters $(n=60$, average BW: $0.5-0.6 \mathrm{~kg})$ in the grower phase were adopted for this study. All selected roosters have met the criteria to be fighting roosters and have gone through the complete vaccination program. In the first week, the roosters were acclimatized to the experimental environment and given commercial grower feed (CP-592, PT. Charoen Pokphand Indonesia Tbk.) and drinking water ad libitum. During experiment, a natural light cycle of 12-hours light/ dark was adopted. In the second week, the chickens were started to be given treatment twice a day, namely 7.00 AM and 3.00 PM according to the needs of the chickens with access to fresh and clean drinking water. The health and biosecurity program for experimental animals was strictly implemented under the supervision of field veterinarians.

\section{Experimental Design and Treatments}

The study used a completely randomized design; sixty roosters were divided into four different treatment groups. Each rooster was placed in an individual cage provided with feeding and drinking equipment. Treatment of MR was given for seven weeks by mixing it in a commercial grower feed. The diet contains following nutrients: water content maximum $14 \%$, crude proteins minimum $15 \%$, fats $3 \%$, fibers $8 \%$, ash $8 \%$, Calcium $0.9-1.0 \%$, Phosphor $0.55-$ $1.0 \%$, and amino acids $1.6 \%$. The MR was administered to roosters through feed with respective doses of $0,0.1,0.2$, and $0.4 \mathrm{ml} / \mathrm{kg} /$ day for seven weeks.

\section{Performance of Roosters}

Parameters measured to see the performance of fighting roosters include feed consumption, cumulative weight gain, weekly body weight, average daily growth and feed conversion efficiency (Morbos et al., 2016).

Cumulative voluntary feed intake (CVFI): Cumulative voluntary feed intake in grams was calculated 
as follows:

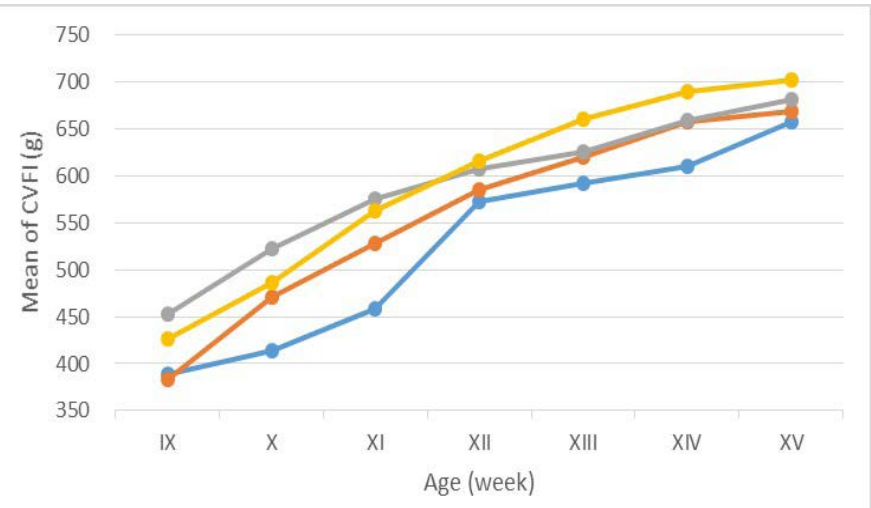

$\longrightarrow$ Control $\longrightarrow 0.1 \mathrm{ml} / \mathrm{kg} \mathrm{NVMR} \longrightarrow 0.2 \mathrm{ml} / \mathrm{kg} \mathrm{NVMR} \longrightarrow 0.4 \mathrm{ml} / \mathrm{kg} \mathrm{NVMR}$

Figure 1: Cumulative voluntary feed intake of grower roosters after treatment of NVMR

Cumulative weight gain (CWG): The cumulative weight gain in grams was calculated as follows:

Note: $\mathrm{BWi}=$ body weight of birds at any specific time period, $\mathrm{BWo}=$ initial body weight.

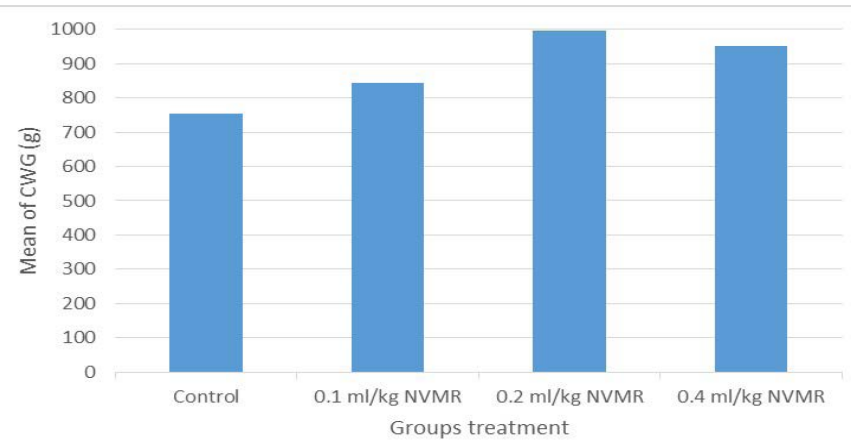

Figure 2: Cumulative body weight gain of grower roosters after treatment of NVMR

Average Daily Gain (ADG): The ADG of the birds was calculated using the formula as:

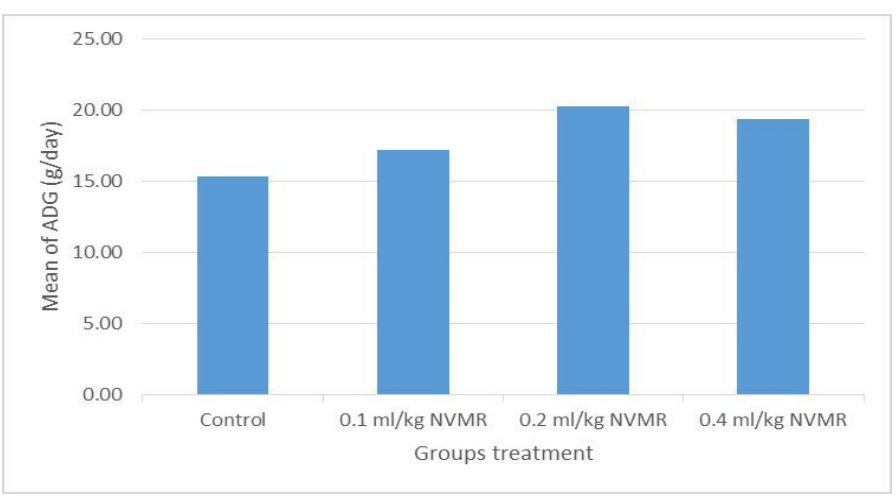

Figure 3: The average daily gain of grower roosters after treatment of NVMR

Feed conversion ratio (FCR): The FCR was calculated as:
Note: CVFI = Cumulative Voluntary Feed Intake, BWi = body weight of birds at any specific time period, $\mathrm{BWo}=$ initial body weight.

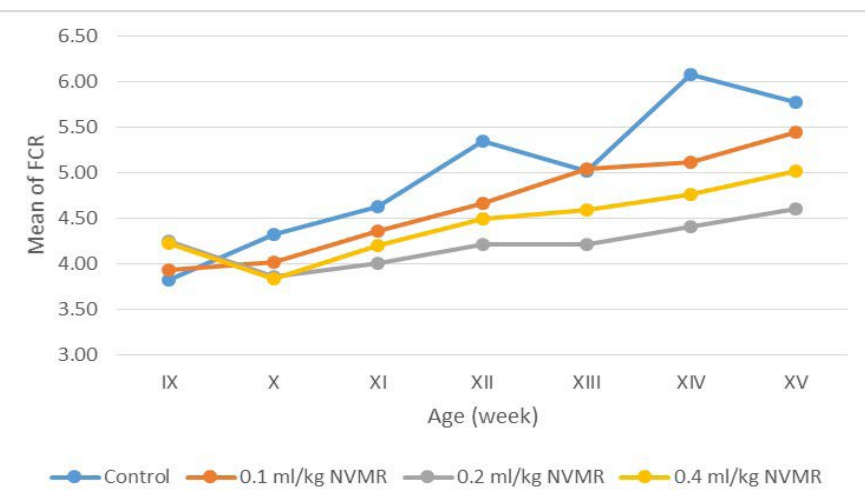

Figure 4: The feed conversion ratio of grower roosters after treatment of NVMR

\section{Bloods Sampling}

A total of $3 \mathrm{ml}$ of blood was collected aseptically through the brachial vein using a $5 \mathrm{ml}$ syringe with a $22 \mathrm{G}$ needle. Then immediately, $1 \mathrm{ml}$ of blood was transferred to a vacutainer tube with EDTA for haematological examination, and $2 \mathrm{ml}$ transferred to a vacutainer tube without anticoagulant for serum biochemistry tests. Blood samples were stored in a cool box with icepacks during transport to the laboratory for further examination.

\section{Hematological Analysis}

Routine blood tests, including red and white blood cell profiles were performed using an Auto Hematology Analyzer (RT-7600, Rayto Life and Analytical Sciences Co., Ltd). The red blood cell profile includes the following parameters: total erythrocytes, haemoglobin, hematocrit, and erythrocyte index. The erythrocyte index includes mean corpuscular volume (MCV), mean corpuscular haemoglobin $(\mathrm{MCH})$, and mean corpuscular haemoglobin concentration (MCHC). Examination of white blood cells includes total and differential leukocytes, including heterophils, lymphocytes, eosinophils, monocytes, basophils, and the ratio of heterophils and lymphocytes $(\mathrm{H} / \mathrm{L}$ ratio).

\section{Blood Chemistry}

Serum samples were processed using the Automatic Hematology Analyzer (Ichem-535Vet, Icubio). The alanine transaminase (ALT) was quantified using an ALT (GPT) IFCC reagent, while aspartate transaminase (AST) using AST (GOT) IFCC reagent (Biorex Diagnostic, UK). The serum creatinine test was checked using Creatinine ST-Reagent (PT. Gresik Sarana Tirta, Indonesia). Examination of blood urea nitrogen (BUN) was done by using the Mocznik / Urea kit reagent (BioMaxima, Poland). All test results were presented in milligrams per deciliter $(\mathrm{mg}$ / dL). 
Table 1: Performance of growing roosters after supplementation of Minyak Rajas (Mean \pm SD)

\begin{tabular}{lllll} 
Parameter & \multicolumn{4}{l}{ Treatment of Minyak Rajas } \\
& Control & $\mathbf{0 . 1} \mathbf{~ m l} / \mathbf{k g}$ & $\mathbf{0 . 2} \mathbf{~ m 1} / \mathbf{k g}$ & $\mathbf{0 . 4} \mathbf{~ m l} / \mathbf{k g}$ \\
Cumulative feed intake $(\mathrm{g})$ & $3.693 \pm 101^{\mathrm{a}}$ & $3.916 \pm 103 \mathrm{~b}^{\mathrm{b}}$ & $4.127 \pm 132^{\mathrm{bc}}$ & $4.144 \pm 96^{\mathrm{c}}$ \\
\hline Weight at 15 weeks $(\mathrm{g})$ & $1.342 \pm 91^{\mathrm{a}}$ & $1.418 \pm 101^{\mathrm{a}}$ & $1.575 \pm 70^{\mathrm{c}}$ & $1.533 \pm 49^{\mathrm{bc}}$ \\
\hline Cumulative weight gain $(\mathrm{g})$ & $759 \pm 69^{\mathrm{ab}}$ & $845 \pm 45^{\mathrm{ab}}$ & $981 \pm 43^{\mathrm{b}}$ & $930 \pm 14^{\mathrm{b}}$ \\
\hline Weekly weight gain $(\mathrm{g})$ & $108 \pm 10.84^{\mathrm{a}}$ & $121 \pm 11.48^{\mathrm{ab}}$ & $140 \pm 9.63^{\mathrm{c}}$ & $132 \pm 13,84^{\mathrm{b}}$ \\
\hline Average daily gain at week 8-15 (g/day) & $15.49 \pm 1.41^{\mathrm{a}}$ & $17.49 \pm 0.96^{\mathrm{b}}$ & $20.02 \pm 1.08^{\mathrm{c}}$ & $18.98 \pm 1.27^{\mathrm{bc}}$ \\
\hline Feed Conversion Ratio & $4.89 \pm 0.38^{\mathrm{a}}$ & $4.64 \pm 0.30^{\mathrm{ab}}$ & $4.21 \pm 0.36^{\mathrm{c}}$ & $4.46 \pm 0.29^{\mathrm{bc}}$
\end{tabular}

Note: mean with different superscripts in the same row indicate significant difference $(\mathrm{P}<0.05)$,

Table 2: Cumulative voluntary feed intake (g) of growing roosters after treatment of Minyak Rajas (Mean \pm SD)

\begin{tabular}{llllllll} 
Dose & Week-9 & Week-10 & Week-11 & Week-12 & Week-13 & Week-14 & Week-15 \\
Control & $389 \pm 28^{\mathrm{a}}$ & $414 \pm 17^{\mathrm{a}}$ & $456 \pm 33^{\mathrm{a}}$ & $573 \pm 33^{\mathrm{a}}$ & $593 \pm 21^{\mathrm{a}}$ & $610 \pm 28^{\mathrm{a}}$ & $658 \pm 30^{\mathrm{a}}$ \\
$0.1 \mathrm{ml} / \mathrm{kg}$ & $384 \pm 32^{\mathrm{a}}$ & $471 \pm 26^{\mathrm{b}}$ & $528 \pm 14^{\mathrm{b}}$ & $586 \pm 19^{\mathrm{ab}}$ & $620 \pm 19^{\mathrm{ab}}$ & $658 \pm 35^{\mathrm{bc}}$ & $669 \pm 24^{\mathrm{ab}}$ \\
$0.2 \mathrm{ml} / \mathrm{kg}$ & $454 \pm 30^{\mathrm{c}}$ & $523 \pm 43^{\mathrm{c}}$ & $576 \pm 34^{\mathrm{c}}$ & $608 \pm 31^{\mathrm{b}}$ & $626 \pm 21^{\mathrm{ab}}$ & $659 \pm 23^{\mathrm{bc}}$ & $681 \pm 31^{\mathrm{bc}}$ \\
$0.4 \mathrm{ml} / \mathrm{kg}$ & $426 \pm 16^{\mathrm{b}}$ & $486 \pm 20^{\mathrm{b}}$ & $563 \pm 23^{\mathrm{c}}$ & $615 \pm 30^{\mathrm{b}}$ & $661 \pm 27^{\mathrm{b}}$ & $690 \pm 31^{\mathrm{c}}$ & $703 \pm 21^{\mathrm{c}}$ \\
\hline
\end{tabular}

Note: mean with different superscripts in the same column indicate significant difference $(\mathrm{P}<0.05)$

Table 3: Cumulative weekly body weight (g) of growing roosters after treatment of Minyak Rajas (Mean \pm SD)

\begin{tabular}{llllllll} 
Dose & Week-9 & Week-10 & Week-11 & Week-12 & Week-13 & Week-14 & Week-15 \\
Control & $676 \pm 47^{\mathrm{a}}$ & $773 \pm 58^{\mathrm{a}}$ & $877 \pm 74^{\mathrm{a}}$ & $986 \pm 88^{\mathrm{a}}$ & $1110 \pm 95^{\mathrm{a}}$ & $1214 \pm 92^{\mathrm{a}}$ & $1342 \pm 91^{\mathrm{a}}$ \\
$0.1 \mathrm{~m} / \mathrm{kg}$ & $671 \pm 64^{\mathrm{a}}$ & $790 \pm 68^{\mathrm{a}}$ & $912 \pm 86^{\mathrm{a}}$ & $1038 \pm 93^{\mathrm{ab}}$ & $1163 \pm 87^{\mathrm{a}}$ & $1293 \pm 93^{\mathrm{a}}$ & $1418 \pm 101^{\mathrm{a}}$ \\
$0.2 \mathrm{ml} / \mathrm{kg}$ & $703 \pm 49^{\mathrm{a}}$ & $839 \pm 46^{\mathrm{b}}$ & $983 \pm 48^{\mathrm{c}}$ & $1128 \pm 65^{\mathrm{c}}$ & $1277 \pm 81^{\mathrm{c}}$ & $1427 \pm 74^{\mathrm{c}}$ & $1575 \pm 70^{\mathrm{c}}$ \\
$0.4 \mathrm{ml} / \mathrm{kg}$ & $698 \pm 43^{\mathrm{a}}$ & $825 \pm 48^{\mathrm{ab}}$ & $959 \pm 67^{\mathrm{bc}}$ & $1096 \pm 46^{\mathrm{bc}}$ & $1240 \pm 60^{\mathrm{b}}$ & $1385 \pm 69^{\mathrm{b}}$ & $1533 \pm 49^{\mathrm{bc}}$ \\
\hline
\end{tabular}

Note: mean with different superscripts in the same column indicate significant difference $(\mathrm{P}<0.05)$

Table 4: The average daily gains of growing roosters after treatment of Minyak Rajas (Mean \pm SD)

\begin{tabular}{llllllll} 
Dose & Week-9 & Week-10 & Week-11 & Week-12 & Week-13 & Week-14 & Week-15 \\
Control & $13.6 \pm 1.4$ & $13.9 \pm 2.1^{\mathrm{a}}$ & $14.9 \pm 2.0^{\mathrm{a}}$ & $15.6 \pm 2.2^{\mathrm{a}}$ & $16.7 \pm 2.4^{\mathrm{a}}$ & $14.9 \pm 2.2^{\mathrm{a}}$ & $17.0 \pm 2.5^{\mathrm{a}}$ \\
$0.1 \mathrm{~m} / \mathrm{kg}$ & $14.4 \pm 1.5$ & $16.6 \pm 1.9^{\mathrm{ab}}$ & $17.4 \pm 1.5^{\mathrm{b}}$ & $18.0 \pm 2.0^{\mathrm{b}}$ & $17.9 \pm 2.4^{\mathrm{b}}$ & $18.6 \pm 2.0^{\mathrm{b}}$ & $17.9 \pm 2.4 \mathrm{a}^{\mathrm{b}}$ \\
$0.2 \mathrm{~m} / \mathrm{kg}$ & $15.6 \pm 1.1$ & $19.4 \pm 1.1^{\mathrm{c}}$ & $20.1 \pm 1.1^{\mathrm{c}}$ & $21.3 \pm 1.8^{\mathrm{c}}$ & $21.3 \pm 1.6^{\mathrm{c}}$ & $21.4 \pm 1.8^{\mathrm{c}}$ & $21.1 \pm 1.4^{\mathrm{c}}$ \\
$0.4 \mathrm{ml} / \mathrm{kg}$ & $14.6 \pm 1.6$ & $18,1 \pm 0.8^{\mathrm{bc}}$ & $19.1 \pm 1.3^{\mathrm{bc}}$ & $20.6 \pm 1.6^{\mathrm{bc}}$ & $20.6 \pm 1.5^{\mathrm{c}}$ & $20.7 \pm 1.7^{\mathrm{bc}}$ & $20.1 \pm 1.8^{\mathrm{bc}}$ \\
\hline
\end{tabular}

Note: mean with different superscripts in the same column indicate significant difference $(\mathrm{P}<0.05)$

Table 5: The feed conversion ratio of growing roosters after treatment of Minyak Rajas (Mean \pm SD)

\begin{tabular}{|llllllll|} 
Dose & Week-9 & Week-10 & Week-11 & Week-12 & Week-13 & Week-14 & Week-15 \\
\hline Control & $4.33 \pm 0.29^{\mathrm{b}}$ & $4.32 \pm 0.50^{\mathrm{a}}$ & $4.63 \pm 1.05^{\mathrm{a}}$ & $5.05 \pm 0.78^{\mathrm{a}}$ & $5.32 \pm 0.84^{\mathrm{a}}$ & $5.78 \pm 1.24^{\mathrm{a}}$ & $5.58 \pm 1.02^{\mathrm{a}}$ \\
\hline $0.1 \mathrm{ml} / \mathrm{kg}$ & $4.84 \pm 0.46^{\mathrm{a}}$ & $4.10 \pm 0.56^{\mathrm{b}}$ & $4.36 \pm 0.46^{\mathrm{b}}$ & $4.67 \pm 0.36^{\mathrm{b}}$ & $5.04 \pm 0.73^{\mathrm{b}}$ & $5.32 \pm 0.86^{\mathrm{b}}$ & $5.25 \pm 0.85^{\mathrm{b}}$ \\
$0.2 \mathrm{ml} / \mathrm{kg}$ & $4.25 \pm 0.77^{\mathrm{b}}$ & $3.87 \pm 0.50^{\mathrm{c}}$ & $4.01 \pm 0.47^{\mathrm{c}}$ & $4.22 \pm 0.53^{\mathrm{c}}$ & $4.42 \pm 0.46^{\mathrm{c}}$ & $4.51 \pm 0.33^{\mathrm{c}}$ & $4.61 \pm 0.48^{\mathrm{c}}$ \\
$0.4 \mathrm{ml} / \mathrm{kg}$ & $4.23 \pm 0.55^{\mathrm{b}}$ & $3.84 \pm 0.29^{\mathrm{c}}$ & $4.20 \pm 1.38^{\mathrm{bc}}$ & $4.50 \pm 0.32^{\mathrm{bc}}$ & $4.59 \pm 0.57^{\mathrm{bc}}$ & $4.76 \pm 0.49^{\mathrm{bc}}$ & $5.02 \pm 0.50^{\mathrm{bc}}$ \\
\hline
\end{tabular}

Note: mean with different superscripts in the same column indicate significant difference $(\mathrm{P}<0.05)$

Statistical Analysis

The obtained data were analyzed by One-way Analysis of Variance followed by Duncan's test using IBM SPSS statistic 23. The variation among the treatment groups at $5 \%$ level $(\mathrm{p}<0.05)$ was stated as statistically significant

\section{RESULTS}

\section{Chicken Performance}

The cumulative performance of the growing fighting roosters was shown in Table 1, while the detailed weekly performance was exhibited in Table 2, 3, 4 and 5. Statistical analysis showed that MR supplementation in feed had a 
significant effect $(\mathrm{P}<0.05)$ on cumulative feed intake, cumulative body weight, daily weight gain, and feed conversion efficiency when compared to the control group. Overall $0.2 \mathrm{ml} / \mathrm{kg}$ of MR supplementation exhibited superior effects as compared to control and other treatment groups.

\section{Haematology Profile}

The physiological haematology profile of cross-breed fighting rooster supplemented MR were shown in Table 6. Statistical analysis showed that MR supplementation at a dose of $0.2 \mathrm{ml} / \mathrm{kg}$ BW significantly increased $(\mathrm{P}<0.05)$ the total erythrocyte count and MCHC when compared to control, however, it was not significantly different from the other treatment groups. However, total leukocyte count was found reduced $(\mathrm{P}<0.05)$ in 0.1 and $0.2 \mathrm{ml} / \mathrm{kg}$ treatment groups as compared to control. Moreover, all other parameters of the haematological profile were not significantly different and were found within the normal range as reported by other researchers.

\section{Blood Chemistry}

Blood chemistry profile of fighting roosters after MR administration was shown in Table 7. Statistical analysis exhibited that there was no statistical difference $(\mathrm{P}>0.05)$ in biochemical parameters in all treatment and control groups.

\section{DISCUSSION}

The results showed that the supplementation of natural animal medicine MR through feed significantly improved the performance of cross-breed fighting roosters compared to control. MR administration increased feed consumption which resulted in a more efficient increase in body weight and feed conversion (FCR). Good performance was shown in the treatment dose of $0.2-0.4 \mathrm{ml} / \mathrm{kg} \mathrm{BW}$, while the dose of $0.1 \mathrm{ml} / \mathrm{kg}$ BW was not significantly different from the control group. The average body weight of cross-breed fighting roosters supplementated MR at the end of the 15 th week reached $1.575 \pm 70$ grams and FCR $4.21 \pm 0.36$ and with a growth rate of $20.02 \pm 1.08$ grams/ day. The results achieved far exceed the performance of local Balinese roosters which only weigh 1,200 grams at the age of 20 weeks. Another study by Hidayat and Asmarasari (2015) reported the performance of local chickens at the age of 20 weeks for native chickens and reported an average body weight of 1,408 grams with FCR 4.9, while for nunukan chickens it was 1,203 grams with an FCR of 3.6 and in pelung chickens it was 1,663-gram with an FCR of 7.1 .

Increased productivity and health of chickens can achieved with a balanced nutritious diet and the correct medication program, such as vaccinations, vitamins, premixes, etc. (Ar- dana, 2011). MR made from herbal plants contained various active compounds that have pharmacological effects. Quercetin, zingiberene, curcumin, olericin, flavonoids, and triterpenoids are active ingredients of $\mathrm{MR}$ and were reported to have antibacterial, antiseptic, anti-inflammatory, and antioxidant activities (Liu et al., 2010; Anggraeni et al., 2019; Kaliyadasa and Samarasinghe, 2019; Mao et al., 2019; Ahlina et al., 2020). Likewise, monoterpene, sesquiterpene, and lauric eugenol compounds are antibacterial, antiparasitic, antifungal, antioxidant, and antitoxin compounds (Intahphuak et al., 2010; Syahidah et al., 2017; Salehi et al., 2019). Curcuminoids and essential oils are found in the herbs Zingiber sp. and Curcuma sp. (Praskas and Pilerrod, 2010; Shan et al., 2018; Ololade et al., 2020; Ahmad et al., 2020), which have cholesterol-lowering, and hepato-stimulant activities (Spriridonov, 2012).

Essential oils and curcuminoids with hepato-stimulant activity can increase feed intake in poultry. It stimulate the flow of bile from the liver to the gallbladder and forward it to the intestines. At the same time, it stimulates the walls of the gallbladder to secrete bile and also stimulates the secretion of pancreatic juice (Spriridonov, 2012). The secretion of bile and pancreatic juice contains endogenous enzymes such as amylase, lipase, and protease which increasing the digestibility of feed ingredients through the hydrolysis of complex bonds in nutrients (Arriaga et al., 2015). The proteolytic activity maximize the digestibility of crude protein. This mechanism also decreases the viscosity of the digesta, so that it facilitate the transportation of digesta to enter the crypt and pass through the small intestinal villi (Pujianti et al., 2013; Alagawany et al., 2018). It also reduce intestinal peristalsis, which causes the digesta to stay longer in the intestine, and increase the chances of absorption of nutrients by the intestinal villi. Feed intake is directly proportional to growth in farm animals. The optimal absorption of nutrients increase the growth rate and efficiency of the feed conversion ratio. In this study, MR used as a growth promoter which has a significant impact on increasing cumulative feed intake and stimulating chicken growth with more efficient feed conversion (Labban, 2014; Olukosi et al., 2015).

The antioxidant and antitoxin abilities possessed by MR are thought to improve intestinal health through the binding mechanism of free radicals and toxins that contaminate feed (Ahlina et al., 2020). This activity optimizes the function of the intestinal villi in nutrient absorption (Maneewan et al., 2012). Antimicrobial, antiseptic, anti-inflammatory, antifungal, and antiparasitic activities work synergistically in suppressing sub-clinical infection of pathogenic microorganisms (Labban, 2014). The bacteriostatic ability of various active metabolites in MR can act as an alternative to antibiotic growth promoters in chickens. 
Table 6: Hematological profile of growing roosters after supplementation of Minyak Rajas (Mean \pm SD)

\begin{tabular}{|c|c|c|c|c|c|c|}
\hline \multirow[t]{2}{*}{ Parameter* } & \multicolumn{4}{|c|}{ Dose of Minyak Rajas } & \multicolumn{2}{|l|}{ Reference } \\
\hline & Control & $0.1 \mathrm{ml} / \mathrm{kg}$ & $0.2 \mathrm{ml} / \mathrm{kg}$ & $0.4 \mathrm{ml} / \mathrm{kg}$ & $\begin{array}{l}\text { Mahmud et al. } \\
2016\end{array}$ & $\begin{array}{l}\text { Simaraks et al., } \\
2004\end{array}$ \\
\hline Hemoglobin (g/dL) & $10.10 \pm 1.01$ & $11.06 \pm 1.02$ & $11.96 \pm 1.05$ & $10.70 \pm 1.06$ & $10.9-12.0$ & $8-10$ \\
\hline Erythrocytes $\left(10^{6} / \mathrm{ml}\right)$ & $3.09 \pm 0.43^{\mathrm{a}}$ & $3.52 \pm 0.32^{\mathrm{ab}}$ & $3.65 \pm 0.16^{\mathrm{b}}$ & $3.33 \pm 0.80^{\mathrm{ab}}$ & $2.9-3.1$ & $2-3$ \\
\hline Hematocrit (\%) & $29.20 \pm 1.22$ & $31.80 \pm 4.71$ & $32.13 \pm 5.02$ & $30.91 \pm 2.26$ & $25.6-26.8$ & $28-37$ \\
\hline $\mathrm{MCV}(\mathrm{fL})$ & $90.46 \pm 11.91$ & $90.68 \pm 6.82$ & $87.83 \pm 8.67$ & $91.23 \pm 12.01$ & - & $90-140$ \\
\hline $\mathrm{MCH}(\mathrm{pg})$ & $31.23 \pm 4.20$ & $30.30 \pm 7.04$ & $32.38 \pm 0.76$ & $31.95 \pm 3.57$ & - & $35-45$ \\
\hline $\mathrm{MCHC}(\%)$ & $34.5 \pm 2.18^{a}$ & $33.5 \pm 2.15^{\mathrm{ab}}$ & $36.8 \pm 1.64^{b}$ & $35.0 \pm 1.28^{\mathrm{ab}}$ & - & $24-35$ \\
\hline Leukocytes $\left(10^{3} / \mathrm{ml}\right)$ & $22.8 \pm 4.49^{b}$ & $20.5 \pm 2.10^{\mathrm{a}}$ & $17.5 \pm 3.87^{\mathrm{a}}$ & $19.7 \pm 2.72^{\mathrm{ab}}$ & $7.0-9.2$ & $12-30$ \\
\hline Heterophil (\%) & $32.23 \pm 4.01$ & $33.46 \pm 2.47$ & $34.36 \pm 1.52$ & $36.30 \pm 7.87$ & $38.5-40.8$ & $15-40$ \\
\hline Lymphocytes (\%) & $57.56 \pm 2.01$ & $58.23 \pm 1.35$ & $58.56 \pm 3.26$ & $56.86 \pm 9.85$ & $55.6-63.9$ & $45-70$ \\
\hline Eosinophils (\%) & $4.91 \pm 1.64$ & $3.06 \pm 1,01$ & $3.03 \pm 1.65$ & $2.83 \pm 2.21$ & $1.5-2.3$ & $2-9$ \\
\hline Monocytes (\%) & $3.57 \pm 0.30$ & $3.36 \pm 0.68$ & $2.73 \pm 0.96$ & $2.43 \pm 0.74$ & $2-3$ & $1-7$ \\
\hline Basophils (\%) & $1.73 \pm 1.01$ & $1.89 \pm 0.56$ & $2.01 \pm 0.80$ & $1.58 \pm 0.98$ & - & $1-5$ \\
\hline $\mathrm{H} / \mathrm{L}$ ratio & $0.56 \pm 0.08$ & $0.57 \pm 0.05$ & $0.58 \pm 0.09$ & $0.62 \pm 0.06$ & $0.7-0.8$ & $0.3-0.6$ \\
\hline
\end{tabular}

Note: mean with different superscript in the same row indicate significant difference $(\mathrm{P}<0.05)$

* $\mathrm{MCV}=$ mean corpuscular volume; $\mathrm{MCH}=$ mean corpuscular haemoglobin; $\mathrm{MCHC}=$ mean corpuscular haemoglobin concentration; $\mathrm{H} / \mathrm{L}$ ratio $=$ heterophils to lymphocytes ratio

Table 7: Blood biochemistry of roosters after administration of Minyak Rajas (Mean \pm SD)

\begin{tabular}{|c|c|c|c|c|}
\hline \multirow[t]{2}{*}{ Parameter* } & \multicolumn{4}{|c|}{ Dose of Minyak Rajas } \\
\hline & Control & $0.1 \mathrm{ml} / \mathrm{kg}$ of $\mathrm{bw}$ & $0.2 \mathrm{ml} / \mathrm{kg}$ of $\mathrm{bw}$ & $0.4 \mathrm{ml} / \mathrm{kg}$ of bw \\
\hline $\operatorname{AST}(\mathrm{mg} / \mathrm{dL})$ & $262 \pm 28$ & $250 \pm 16$ & $265 \pm 36$ & $251 \pm 27$ \\
\hline $\operatorname{ALT}(\mathrm{mg} / \mathrm{dL})$ & $72 \pm 14$ & $60 \pm 15$ & $62 \pm 6$ & $69 \pm 12$ \\
\hline BUN (mg/dL) & $29.60 \pm 1.30$ & $32.46 \pm 3.95$ & $36.66 \pm 5.52$ & $32.43 \pm 2.55$ \\
\hline Creatinine $(\mathrm{mg} / \mathrm{dL})$ & $1.20 \pm 0.26$ & $0.93 \pm 0.15$ & $1.03 \pm 0.32$ & $1.16 \pm 0.25$ \\
\hline
\end{tabular}

* AST = aspartate transaminase; ALT = alanine transaminase; BUN = blood urea nitrogen

The same thing has been reported to be successful in pigs (Omonijo et al., 2018). The active metabolites in galangal and betel leaf herbs are reported to be antiparasitic, which are effective in relieving worms and coccidia infections (Arham et al., 2016; Salehi et al., 2019). Changes in the acid-base atmosphere in the intestine and suppression of subclinical infections can improve the health status of the digestive system of chickens, and have an impact on improving the performance of the grower phase of fighting roosters.

The haematological and biochemical profiles of blood after administration of MR exhibited the good health status of birds. Although in some parameters, there were values that exceed the normal range from the reference of previous studies, however overall birds exhibited clinically good health. This parameter is the basis for assessing the health status of the animal at a particular time. Blood plays a role in the homeostatic and osmoregulation system. In particular, red blood cells (erythrocytes) have the primary function of transporting oxygen from the lungs to all body tissues and transporting carbon dioxide from the tissues to be excreted through the lungs. This function is played by haemoglobin. It also plays a role in the transportation of nutrients, metabolites, hormones, body heat, and the body's immune delivery mechanisms (Pittman, 2011; Klein, 2013). Statistical analysis showed that MR supplementation was able to increase the total erythrocytes significantly $(\mathrm{P}<0.05)$ in the treatment group at the dose of $0.2 \mathrm{ml} / \mathrm{kg} \mathrm{BW}$, but it was not significant in 0.1 and $0.4 \mathrm{ml} / \mathrm{kg}$ BW doses compared to control (Table 6). The antioxidant content of this natural veterinary medicine probably provides an anti-oxidation protective effect on the membranes of blood cells. Antioxidant activity can act as a free radical scavenger by eliminating and inhibiting the formation of superoxide. It is suspected that this antioxidant mechanism can extend the life span of chicken blood cells given MR while the production of new blood cells continues under normal conditions. In general, the lifespan of avian red blood cells is no more than fifty days with a range of 4-9 weeks. In the group given MR, the increase of total erythrocytes was in line with the increase in hematocrit and haemo- 
globin. This increase was slightly higher than the normal range reported by Simaraks et al. (2004), but in the normal range, as shown in Table 6 . This condition probably indicates that the rooster is experiencing relative erythrocytosis, as response to hot weather to avoid dehydration. Besides, chickens are in high metabolic conditions to spur growth. Therefore, the presence of erythrocytes and higher haemoglobin concentration assured to meet the needs of transporting nutrients and oxygen to various tissues, as well as removing the waste metabolites and gases from the body tissues. Other haematological parameters that were seen to be increased were heterophils, lymphocytes, and total leukocytes but were still in the normal range. This is very likely to be influenced by environmental stress, due to the wide temperature difference between day and night. Another thing is the immune response of the Newcastle disease vaccination (at 12 weeks of age), which causes an increase in total leukocytes, especially the level of eosinophils (Kongroi and Likitdacharote, 2019).

The biochemistry examination of blood includes aminotransferase enzyme activity, serum urea, and creatinine levels. The existence of aminotransferase enzyme activity, including SGOT and SGPT, is used as a predictor of liver function disorders. Meanwhile, the presence of serum urea and creatinine are used as predictors of impaired kidney function. If the liver or kidney is damaged, the parameter value will increase. Statistical analysis showed that there was no significant difference $(\mathrm{P}>0.05)$ in all MR supplemented groups compared to controls. It can be concluded that MR supplementation at a dose of 0.1-0.4 ml/ $\mathrm{kg}$ BW through feed did not cause liver and kidney function disorders in fighting chickens.

\section{CONCLUSION}

Natural veterinary medicine, MR at a dose of $0.2 \mathrm{ml} / \mathrm{kg} /$ day showed the best results by significantly increasing cumulative feed intake, cumulative weight gain, average daily gain, and feed conversion efficiency of fighting chickens in the grower phase. It also increased some haematological indices (viz., total erythrocytes and MCHC), while other haematological varibales and blood biochemistry indices were in the normal range. Thus, MR supplementation could be recommended to the fighting roosters to improve the performance and health status during growing stage.

\section{ACKNOWLEDGEMENTS}

The authors would gratefully thank the Director of PT Songgolangit Persada, Denpasar, Bali, and also to the Dean of the Faculty of Veterinary Medicine, Udayana University for the research facilities and funding.

\section{CONFLICT OF INTEREST}

The author states there is no conflict of interest.

\section{AUTHORS CONTRIBUTION}

IWS and AAGA designed the research. IMM, LMS and IWNFG carried out the research, analyzed data and wrote the manuscript. IWS and IMM proofread the manuscript.

\section{REFERENCES}

-Ahlina FN, Nugraheni N, Salsabila IA, Haryanti S, Da'i M, Meiyanto E (2020). Revealing the reversal effect of galangal (Alpinia galanga L.) extract against oxidative stress in metastatic breast cancer cells and normal fibroblast cells intended as a Co- Chemotherapeutic and anti-ageing agent. Asian Pac. J. Cancer Prev. 21(1):107-117. https://doi. org/10.31557/APJCP.2020.21.1.107

- Ahmad RS, Hussain MB, Sultan MT, Arshad MS, Waheed M, Shariati MA, Plygun S, Hashempur MH (2020). Biochemistry, safety, pharmacological activities, and clinical applications of turmeric: a mechanistic review. eCAM. Vol 2020, Article ID 7656919, 14 pages. https://doi. org/10.1155/2020/7656919

-Alagawany M, Elnesr SS, Farag MR (2018). The role of exogenous enzymes in promoting growth and improving nutrient digestibility in poultry. IJVR. 19(3): 157-164.

-Anggraeni N, Syamsunarno MRA, Widyastuti R, Puspitasari IM, Praptama S (2019). Potential dual effect antiinflammatory and anti-platelet of cogon grass ethanol extract on diabetic mice a preliminary study. IOP Conf. Series: J. Physics. 1246:012006. https://doi.org/10.1088/17426596/1246/1/012006

-Ardana IBK (2011). Strategi Pencegahan Penyakit Inefeksius Pada Peternakan Broiler Berbasis Laboratorium. Buletin Vet. Udayana. 3(1):51-59.

-Arham S, A Khumaidi, R Pitopang (2016). Keanekaragaman Jenis Tumbuhan Obat Tradisional dan Pemanfaatannya pada Suku Kulawi di Desa Mataue Kawasan Taman Nasional Lore Lindu. Biocelebes. 10(2): 1-16.

-Arriaga AIM, Ayala EE, García PAH, Molina OM (2015). Use of exogenous enzyme in animal feed. Life Sci. J. 12(2): 2332 .

-Astarina NWG, Astuti KW, Warditiani NK (2013). Skrining Fitokimia Ekstrak Metanol Rimpang Bangle (Zingiber purpureum Roxb.). J. Farmasi Udayana. 2(4).

- Hidayat C, SA Asmarasari (2015). Native Chicken Production in Indonesia: A Review. J. Peternakan Indonesia. 17(1): 1-11. https://doi.org/10.25077/jpi.17.1.1-11.2015

-Intahphuak S, Khonsung P, Panthong A (2010). Antiinflammatory, analgesic, and antipyretic activities of virgin coconut oil. Pharm. Biol. 48(2):151-7. https://doi. org/10.3109/13880200903062614

-Kaliyadasa E, Samarasinghe BA (2019). Genus alpinia, a potential power house of bioactives: a review. Int. J. Pharm. Sci. Res. 10(6):2644-2653.

-Katzung BG (2004). Basic \& Clinical Pharmacology. 9th. The McGraw-Hill Companies. United State.

-Klein BG (2013). Cunningham's text book of Veterinary Physiology. Fifth Edition. St. Louis, Missouri: by Elsevier, 
Inc.

-Kongroi K, Likitdacharote B (2019). The relationship of hematological values with Newcastle disease antibody in Thai indigenous chicken: strain Leung Hang Khao. Int. J. Agric. Technol. 15(2): 309-318.

- Labban L (2014). Medicinal and pharmacological properties of turmeric (Curcuma longa): a review. Int. J. Pharm. Biomed. Sci. 5(1):17-23.

-Liu RH, Fu LN, Chen LY, Ren G., Chen SS, Chen Z (2010). Chemical constituents and pharmacology study of Imperata cylindrical rhizomes. J. Tradit. Chin. Med. 22(4): 80-83.

- Mahmud ATBA, Afnan R, Ekastuti DR, Arief II (2016). Blood Profile, Performans and Meat Quality ff Crossed Kampung Broiler Chicken in Different Stocking Density. J. Vet. 18(2): 247-256.

-Maneewan C, K Yamauchi, A Mekbungwan, B Mmaneewan dan S Siri (2011). Effect of turmeric on growth performance, nutrient digestibility, hematological value and intestinal histology in nursery pig. J. Swine Health Prod. 20(5): 231240.

- Mao QQ, Xu XY, Cao SY, Gan RY, Corke H., Beta T, Li HB (2019). Bioactive Compounds and Bioactivities of Ginger (Zingiber officinale Roscoe). Foods. 8(6):185. https://doi. org/10.3390/foods8060185

-Merdana IM, Watiniasih NL, Sudira IW, Samsuri (2019). The Effect of Ethanol Extract Mymercodia pendans on Paracetamol-Induced Hepatotoxicity in White Rats. IOP Conf. Ser.: Earth Environ. Sci. 248 012045. https://doi. org/10.1088/1755-1315/248/1/012045

- Mustchler E (2001). Dinamika Obat. Terjemahan: M.B. Widianto dan A.S. Ranti. Penerbit ITB. Bandung.

- Nataamijaya AG (2010). Pengembangan Potensi Ayam Lokal untuk Menunjang Peningkatan Kesejateraan Petani. J. Litbang Pertanian. 29(4):131-138.

- Ololade ZS, Abam EO, Anuoluwa IA, Abiona OO (2020). Secondary metabolites, pharmacognostic and therapeutic activities of the rhizome extract of Curcuma longa grown in South-West, Nigeria. J. Phytopharmacol. 9(1):30-37. https://doi.org/10.31254/phyto.2020.9106

- Olukosi OA, Benson LA, Englyst K, Romero LF (2015). Effects of exogenous proteases with or without carbohydrases on nutrient digestibility and disappearance of non-starch polysaccharides in broiler chicken. Poult. Sci. 94(11): 26622669. https://doi.org/10.3382/ps/pev260

- Omonijo FA, Ni L, Gong J, Wang Q, Lahaye L, Yang C (2018). Essential oils as alternatives to antibiotics in swine production. Anim. Nutrit. 4:126-136. https://doi. org/10.1016/j.aninu.2017.09.001

- Pittman RN (2011). Regulation of tissue oxygenation. Virginia: Morgan \& Claypool Life Sciences.

- Praskash J, Pilerood SA (2010). Chemical Composition and Antioxidant Properties of Ginger Root (Zingiber officinale). J. Med. Plants Res. 4(24):2674-2679. https://

\section{doi.org/10.5897/JMPR09.464}

-Pujianti NA, A. Jaelani dan N. Widaningsih (2013). Penambahan tepung kunyit (curcuma domestica) dalam ransum terhadap daya cerna protein dan bahan kering pada ayam pedaging. Ziraa'ah. 36 (1) : 49-59.

- Rohaimi M, Shah M, Sabariah I, Roziahanim M (2012). Standarization and phytochemical Studies of Curcuma xanthorrhiza Roxb. Int. J. Pharm. Pharmaceut. Sci. 4(3): 606-610.

-Salehi B, Zakaria ZA, Gyawali R, Ibrahim SA, Rajkovic J, Shinwari ZK, Khan T, Sharifi-Rad J, Ozleyen A, Turkdonmez E, Valussi M, Tumer TB, Monzote FL, Martorell M, Setzer WN (2019). Piper species: a comprehensive review on their phytochemistry, biological activities and applications. Molecules. 24(7):1364. https:// doi.org/10.3390/molecules24071364

- Shan CY, Iskandar Y (2018). Studi Kandungan Kimia dan Aktivitas Farmakologi Tanaman Kunyit (Curcuma longa L.). Farmaka. 16(2): 547 - 554.

- Simaraks S, Chinrasri O, Aengwanich S (2004). Hematological, electrolyte and serum biochemical values of the Thai indigenous chickens (Gallus domesticus) in northeastern, Thailand. Songklanakarin J. Sci. Technol. 26(3): 425-430.

- Simoh S, Zainal A (2015). Chemical profiling of Curcuma aeruginosa Roxb. rhizome using different techniques of solvent extraction. Asian Pac. J. Trop. Biomed. 5(5): 412417. https://doi.org/10.1016/S2221-1691(15)30378-6

- Syahidah A, Saad CR, Hassan MD, Rukayadi Y, Norazian MH, Kamarudin MS (2017). Phytochemical Analysis, Identification and Quantification of Antibacterial Active Compounds in Betel Leaves, Piper betle Methanolic Extract. Pak. J. Biol. Sci. 20(2):70-81. https://doi.org/10.3923/ pjbs.2017.70.81

- Spiridonov NA (2012). Mechanisms of action of herbal cholagogues. Med. Aromat. Plants. 1(5):1-5.

-Morbos CE,Espina DM,BestilLC (2015). Growth Performance of Philippine Native Chicken Fed Diet Supplemented with Varying Levels of Madre de Agua (Trichanthera gigantea Nees) Leaf Meal. Ann. Trop. Res. 38(1): 174-182. https:// doi.org/10.32945/atr38115.2016

- Maria U, Dyah P, Jakaria M, Achmad F (2015). Breed Determination for Indonesian Local Chickens Based on Matrilineal Evolution Analysis. Int. J. Poult. Sci. 14 (11): 615-621. https://doi.org/10.3923/ijps.2015.615.621

-Ulfah M, Perwitasai D, Jakaria, Muladno, Farajallah A (2015). Breed Determination for Indonesian Local Chickens Based on Matrilineal Evolution Analysis. Int. J. Poult. Sci. 14 (11): 615-621. https://doi.org/10.3923/ijps.2015.615.62

-Vasinopas L, W Meckvichai (2015). The difference of morphological characteristics between fighting and meat type Thai native chickens. Khon Kaen Agr. J. 43(Suppl. 2): 70-73. 